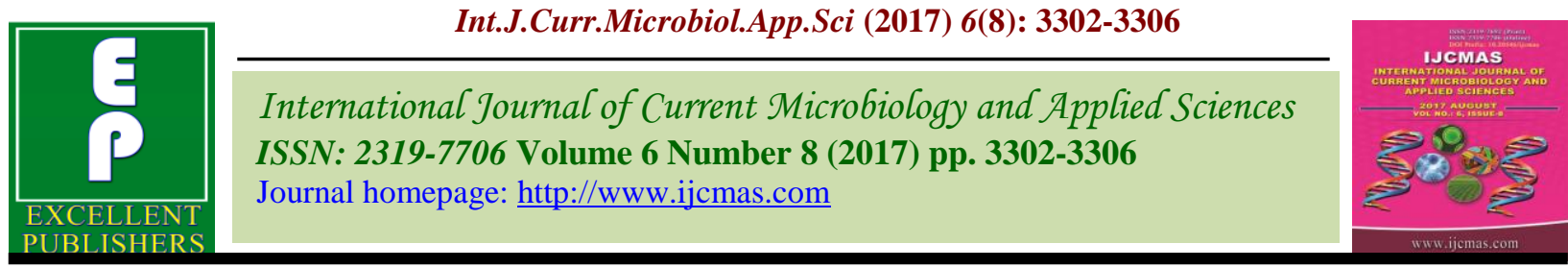

Original Research Article https://doi.org/10.20546/ijcmas.2017.608.394

\title{
Antibacterial Activity of a Novel Bacillus cereus isolated from Mangrove Ecosystem
}

\section{Kandasamy Karthikeyan* and Joseph Sahayarayan}

\author{
Department of Food Science and Nutrition, Periyar University, Salem 636011, \\ Tamil Nadu, India \\ Department of Bioinformatics, Alagappa University, Karaikudi 630003, India \\ *Corresponding author
}

\section{A B S T R A C T}

Keywords

Mangrove,

Bacillus cereus,

Antimicrobial activity, Muthupet mangrove, E. coli.

Article Info

Accepted:

26 June 2017

Available Online:

10 August 2017
Mangrove forests are highly nutrient rich environment paves the way to the microbially vibrant ecosystem. Bacteria survive in this ecological niche tend to produce symbiotic or antagonistic metabolites, which is vital for many biotechnological applications. Muthupet mangrove is one of the important mangrove forests in India. In the present study, isolated some bacterial strains and the isolated strains were subjected to screen its antibacterial potential against human pathogenic bacteria. The antimicrobial assay showed one potential bacterium could able to produce antibacterial compound against enterobacteria members. The highest activity was recorded against $E$. coli. Phenotypic characterization of the active isolate proved that the isolate is Bacillus cereus. The antimicrobial compound produced by $B$. cereus showed its promising biotechnological application.

\section{Introduction}

Coastal region is a vital marine ecosystem which connects land and ocean, this can be categorized as estuaries, coral reefs, intertidal zones, lagoons, mangroves and salt marshes (Chai et al., 2017; Balakrishnan et al., 2017; Vasanthi et al., 2014; Jha et al., 2013; Ganesh Kumar et al., 2010). Mangrove forests are multifaceted and vibrant ecosystem acting as a shelter for many living things adjacent to the coastal ecosystem (Chai et al., 2017; Balakrishnan et al., 2017). Mangroves also act as fencing between the coastal and estuarine ecosystem. Plant species present in this environment tend to tolerate high amount of salt concentration, thus providing shelter and food for many associated plants and animals in the ecosystem (Baskar and PrabaKaran 2011a, 2011b and 2015). Mangrove ecosystem are rich in nutrients allows high diversity of microbial community compared to terrestrial ecosystem (Balakrishnan et al., 2017). This vast diversity of the microbes increases its metabolic and genetic capability of showing unique phenotypic characters, and the characters are beneficial in many ways to the human community (Balakrishnan et al., 2017; Baskar and PrabaKaran 2015). There are several research work reported on antimicrobial compound production, plant growth promoter 
producing, bioremediation and many more biotechnological activities reported from mangrove associated microorganisms (Balakrishnan et al., 2017; Baskar and PrabaKaran 2015; Prakash et al., 2015). Producing antimicrobial compounds is one of the major survival properties of bacterial population present in mangrove (Prakash et al., 2015; Balakrishnan et al., 2014). Thus it can compete with other microbial community present in the highly competitive niche. In the present study, isolated a potential antibacterial compound producing bacterium from Muthupet mangrove ecosystem, located on the southeast coast of India. The isolated bacteria identified using phenotypic characteristics and evaluated its antimicrobial potential against pathogenic bacteria.

\section{Materials and Methods}

\section{Isolation of bacteria}

Soil samples were collected from dense mangrove forest area of Muthupet mangrove ecosystem $\left(10^{\circ} 20^{\prime} 20.5^{\prime \prime} \mathrm{N} 79^{\circ} 32^{\prime} 36.8^{\prime \prime E}\right)$. In a sterile container, $10 \mathrm{~g}$ of soil sample collected and transported immediately to the laboratory. Collected samples subjected to extraction by adding $10 \mathrm{ml}$ of Phosphate Buffer Saline (PBS) and vortexing for $2 \mathrm{~min}$.

After extraction $1 \mathrm{ml}$ of the extracted content transferred into a tube containing $9 \mathrm{ml}$ of sterile PBS. The content was mixed well by vortexing, and subjected for serial dilution. From dilution 5, 6 and 7 one milliliter of the sample taken and plated onto a Zobel marine agar. The plates were Incubated for $24 \mathrm{hrs}$ at $37{ }^{\circ} \mathrm{C}$. After incubation; individual colonies were selected and streaked on a new ZMA plates.

\section{Antibacterial assay}

Each isolated colonies were subjected to antimicrobial production test, for that the bacteria was grown into the ZMB for $18 \mathrm{hrs}$ at $37{ }^{\circ} \mathrm{C}$. After incubation supernatant was collected using centrifugation. $20 \mu \mathrm{L}$ collected supernatant transferred to an agar plate containing $5 \mathrm{~mm}$ wells and streaked with desired pathogen (Table 1). The plate was incubated for $18 \mathrm{hrs}$ at $37{ }^{\circ} \mathrm{C}$. After incubation the plates were observed for the presence of a zone of inhibition (Balakrishnan et al., 2014). The size of inhibition zone was recorded.

\section{Characterization of potential bacteria}

For characterizing the active isolate of the study, experiments were performed as described in Bergey's Manual of Systematic Bacteriology (Logan and Vos, 2015).

\section{Results and Discussion}

Among 83 isolates isolated 4 of them showed antimicrobial activity. Among the four active isolates, one of the isolates showed excellent activity. Phenotypic characterization results were compared with Bergey's Manual of Systematic Bacteriology and revealed that isolate is Bacillus cereus (Logan and Vos, 2015) (Table 1).

Among the ten pathogenic bacteria used in the study, B. cereus showed its antibacterial activity against five bacteria. All the five sensitive bacteria are gram negative; this means the bacteria $B$. cereus isolated in the study produces antibacterial substances against a wide range of Gram-negative bacteria.

Like this many gram-positive bacteria were reported for production of the antimicrobial compound against Gram-negative bacteria (Hu et al., 2017; Sumi et al., 2014). Also, the all sensitive bacteria in the study come from the Enterobacteriaceae family; these are considered to be highly pathogenic to the human. 
Table.1 Phenotypic characters of B. cereus

\begin{tabular}{lclclc}
\hline Test & Result & Test & Result & Test & Result \\
\hline Colony colour & White & $\mathrm{H}_{2}$ S Production & - & Glucose & + \\
Grams staining & + & Catalase & + & Glycerol & + \\
Motility & + & Oxidase & + & Inositol & - \\
Spore production & + & Urease & + & Lactose & + \\
pH range & $4-10$ & Gelatinase & + & Maltose & + \\
Optimum pH & $7 \pm 0.2$ & Nitrate Reductase & + & Mannitol & + \\
Temperature ${ }^{\circ} \mathrm{C}$ & $10-45$ & Arginine decarboxylase & + & Mannose & - \\
Optimum ${ }^{\circ} \mathrm{C}$ & $37 \pm 0.2$ & Lysine decarboxylase & - & Raffinose & - \\
Range of $\mathrm{NaCl}(\%)$ & $0.5-10$ & Ornithin decarboxylase & - & Rhamnose & - \\
Optimum $\mathrm{NaCl}(\%)$ & 0.5 & Arabinose & + & Sorbitol & + \\
Indole & - & Cellobiose & + & Sucrose & + \\
Methyl Red & + & Dextrose & - & Starch & + \\
Voges Proskauer & + & Fructose & + & Trehalose & + \\
Citrate & + & Galactose & - & Xylose & - \\
\hline
\end{tabular}

Table.2 Antibacterial activity of B. cereus

\begin{tabular}{lc}
\hline \multicolumn{1}{c}{ Type strains } & Zone of Inhibition (mm) \\
\hline Bacillus subtilis & - \\
Enterococcus faecalis & - \\
Escherichia coli & 13.1 \\
Klebsiella pneumonia & 10.7 \\
Micrococcus luteus & - \\
Proteous mirabilis & 12.2 \\
Pseudomonas aeroginosa & - \\
Salmonella enteric ser typhi & 7.2 \\
Shigella flexineri & 8.9 \\
Staphylococcus aureus & - \\
\hline
\end{tabular}

In recent years many new pathogenic strains from the family of Enterobacteriaceae threatening human life by changing its pathogenicity and resisting many commercially used antimicrobial compounds (Balakrishnan et al., 2016; Barizuddin et al., 2015).

The highest activity was recorded against $E$. coli (Table 2); this is the dominant species of bacteria present in the human gastrointestinal tract tent to change its genotype and cause many life threatening diseases (Balakrishnan and Mobley 2017; Balakrishnan et al., 2016).
The antibacterial compound produced by $B$. cereus can be used as a drug against Gramnegative pathogens. However, before the application, there are a lot of work needs to be done to proves its specificity and toxicity to the humans. Nowadays it is also important to consider its effect on inducing antimicrobial resistance in bacteria.

\section{Acknowledgement}

Author thankful to Dr. T. Poongodi Vijayakumar and Dr. J. Prakash Maran (Department of Food Science and Nutrition, 
Periyar University) for the constant support and encouragement in doing research.

\section{References}

Balakrishnan, B., and Mobley, G. 2017. Next in Human Microbiome Research. EC Microbiol. 6 (6) 91-92.

Balakrishnan, B., Barizuddin, S., Wuliji, T. and El-Dweik, M. 2016. A rapid and highly specific immunofluorescence method to detect Escherichia coli O157:H7 in infected meat samples. Int. J. Food Microbiol. 231: 54-62. doi.org/10.1016/j.ijfoodmicro.2016.05.0 17.

Balakrishnan, B., Ranishree, J.K., Thadikamala, S. and Panchatcharam, P. 2014. Purification, characterization and production optimization of a vibriocin produced by mangrove associated Vibrio parahaemolyticus. Asian Pac. J. Trop. Biomed. 4: 253-261. doi.org/10.12980/APJTB.4.2014C947

Balakrishnan, B., Sahu, B.K., Ranishree, J.K., Lourduraj, A.V., Nithyanandam, M., Packiriswamy, N. and Panchatcharam, P. 2017. Assessment of heavy metal concentrations and associated resistant bacterial communities in bulk and rhizosphere soil of Avicennia marina of Pichavaram mangrove, India. Environ. Earth Sci. 76: 58. doi.org/10.1007/s12665-016- 6378-7.

Barizuddin, S., Balakrishnan, B., Stringer, R.C. and Dweik, M. 2015. Highly specific and rapid immuno-fluorescent visualization and detection of $E$. coli O104:H4 with protein-A coated magnetic beads based LST-MUG assay. J. Microbiol. Methods. 115: 27-33. doi.org/10.1016/j.mimet.2015.05.017.

Baskar and PrabaKaran 2011a. Characterization of mangrove associated nitrogen fixing halophilic bacterium Panibacillus sp. Int. J. Curr.
Res. 3(9): 065-067.

Baskar, B., and PrabaKaran, B. 2011b. Isolation and characterization of copper resistant Exiguobacterium strains isolated from rhizosphere soil of Avicennia marina. Res. J. Pharm. Biol. Chem. Sci. 2(4): 640-646.

Baskar, B., and PrabaKaran, B. 2015. Assesment of nitrogen fixing bacterial community present in the rhizosphere of Avicennia marina. Indian J. Geomar. Sci. 44(3): 318-322.

Chai, M., Li, R. and Zan, Q. 2017. Effects of Mangrove plants on heavy metal risk in sediment based on SEM-AVS analysis. Reg. Stud. Mar. Sci. 13: 12-18.

Ganesh Kumar, A., Baskar, B., Santhanakumar, J., Vinithkumar, N.V., Vijayakumaran, M. and Kirubagaran, R. 2010. Diversity and functional properties of intestinal microbial flora of the spiny lobster Panulirus versicolor (Latreille, 1804). J. Mar. Biol. Ass. India. 52(2): 282-285.

Hu, Y., Liu, X., Shan, C., Xia, X., Wang, Y., Dong, M. and Zhou, J. 2017. Novel bacteriocin produced by Lactobacillus alimentarius $\mathrm{FM}^{-\mathrm{MM}_{4}}$ from a traditional Chinese fermented meat Nanx Wudl: Purification, identification and antimicrobial characteristics. Food Control. 77: 290-297. doi.org/10.1016/j.foodcont.2017.02.007 Jha, D.K., Vinithkumar, N.V., Marimuthu, N., Baskar, B., Da,s A.K., Sahu, B.K. and Kirubagaran, R. 2013. Field and GIS based assessment of scleractinian coral cover in the Aerial Bay group of islands, north Andaman, India. J Coast Conserv. $\quad 17$ : 671-677. doi:10.1007/s11852-013-0266-z.

Logan, N A., and Vos, P.D. 2015. Bacillus. Bergey's Manual of Systematics of Archaea and Bacteria. 1-163. doi: 10.1002/9781118960608.gbm0053 0 . 
Prakash, S., Ramasubburayan, R., Iyapparaj, P., Ahila, N.K., Ramkumar, V.S., Palavesam, A., Immanuel, G. and Kannapiran, E. 2015. Influence of physicochemical and nutritional factors on bacterial diversity in mangrove sediments along the southwest coast of Tamilnadu, India. Environ. Monit. Assess. 187: 562.

Sumi, C.D., Yang, B.W., Yeo, I.C. and Hahm, Y.T. 2014. Antimicrobial peptides of the genus Bacillus: a new era for antibiotics. Can. J. Microbiol. 61(2): 93-103.

Vasanthi, L.A., Muruganandam, A., Revathi, P., Baskar, B., Jayapriyan, K., Baburajendran, $\mathrm{R}$ and Munuswamy, N. 2014. The application of histocytopathological biomarkers in the mud crab Scylla serrata (Forskal) to assess heavy metal toxicity in Pulicat Lake, Chennai. Mar. Pollut. Bull. 81: 85-93. doi.org/10.1016/j.marpolbul.2014.02.01

6.

\section{How to cite this article:}

Kandasamy Karthikeyan and Joseph Sahayarayan. 2017. Antibacterial Activity of a Novel Bacillus cereus Isolated from Mangrove Ecosystem. Int.J.Curr.Microbiol.App.Sci. 6(8): 33023306. doi: https://doi.org/10.20546/ijcmas.2017.608.394 